\title{
PHYSICAL QUALITY AND PRODUCTIVITY OF COCOA BEAN (Theobroma cacao L.) BASED ON CANOPY POSITION AND PLANT AGE
}

\author{
Sarawa $^{1^{*}, \text { Halim }^{2} \text {, Dirvamena Boer }}{ }^{3}$, Asriningsih ${ }^{4}$ \\ ${ }^{I}$ Specification of Plant Physiology, Department of Agrotechnology, Faculty of Agriculture, \\ Halu Oleo University, Kendari, Southeast Sulawesi, Indonesia \\ ${ }^{2}$ Specification of Agrotechnology, Department of Agrotechnology, Faculty of Agriculture, \\ Halu Oleo University, Kendari, Southeast Sulawesi, Indonesia \\ ${ }^{3}$ Specification of Plant Breeding, Department of Agrotechnology, Faculty of Agriculture, \\ Halu Oleo University, Kendari Southeast Sulawesi, Indonesia \\ ${ }^{4}$ Department of Soil Sciences, Faculty of Agriculture, Halu Oleo University, Kendari, Southeast Sulawesi, \\ Indonesia
}

*Correspondence Author: Sarawa

Article DOI: https://doi.org/10.36713/epra8091 DOI No: 10.36713/epra8091

\begin{abstract}
The research aimed to study the cocoa bean quality and productivity based on their position on canopy and different plant ages. This has been conducted at cocoa farming area at Wonggeduku Subdistrict, Konawe Regency, Southeast Sulawesi Province. These treatments were arranged based on the nested design in which the pod position on the canopy i.e. on main stem, primary and secondary branches, and nested to the plant ages i.e. 8,10, 12, and 14 years old were used. The observed variable were pod length, pod diameter, seed weight, seed number, and dry production per pod. The data gathered were analysed by analysis of variance and the difference between treatments were justified by Duncan's Multiple Range Test at 95\% significant level. To study the relationship between plant ages and pod position on canopy, the regression analysis was applied. Research result showed that there were interaction effect on pod position and ages on all variable observed. The best treatment on the main stem and primary branch at eight year age of the plant was on the length, diameter and weight of pods, seed number, and dry seed production per pod.
\end{abstract}

KEY WORDS: Cocoa pod, plant age, pod position, production, quality

\section{INTRODUCTION}

Cocoa (Theobroma cacao L.) was the biggest commodity export of Indonesia government from year to year with 326,815 tons in 2015 which increasing 7.4\% from 2014. Indonesian government via Ministry of Trade have always been increasingly the production of national cocoa in 2020 on 1.2 million tons. Indonesian cocoa bean was the biggest exportir after palm oil and rubber [1].
International commission of cocoa organization (ICCO) have reported that in 2016 the cocoa production was achieved 3.971 million tons, while the world needed will be in 4.1 million tons, so that there were 197,000 tons have to be produced, and the world prediction in 2020 have reached in 4.7 million tons [2]. By this obstacle, the Indonesian govenment have opportunity to rise cocoa production for international market [3]. 
The production quantity and quality of cocoa bean have to be increased in both Indonesian government and farmers. It is depend upon the genetical, environmental and management of factors. The environmental factors that affected the cocoa production were altitude, contour, physical properties of the soil, viz. sand and loam fractions, $\mathrm{pH}$, carbon organic, nitrogen total, phosporus availability, Alexchanged, and cation exchange capasity (CEC) [4]. The climatic factors like rain, humidity, and sunray intensity, also win speed were those factors that affected the plant metabolism prosesses, for example the plant growth, quality and quantity production including the physical and chemical composition of cocoa bean [5].

The quality of cocoa bean obtained was strongly related to the managerial plantation and production mainly to the post harvest practiced [6]. Besides, the physical, chemical, and microbiologis of the cocoa bean were the most important factors that determined the quality of the cocoa bean. Physical characteristics of cocoa bean was used to bean grouping based on their physical performances. The pod position in the main, primary, and secondary stem, were expected to have the physical and chemical quality of differentiation. It is based on the Kusumastuti [7], statement that the cocoa bean that lied on the main stem, primary and secondary branches have the different quality of the seeds resulted. From explanation above, the important research must be done to study the effect of cocoa been position on the canopy and plant age on the physical quality of cocoa bean.

\section{MATERIALS AND METHODS \\ Research Location and Time}

This research was done in Wonggeduku Subdistrict Konawe Regency Southeast Sulawesi on 2018. The experimetal tolls were used like basket, cocoa pods, scissors, container, and scale.

\section{Sample Determination}

The nested design was used and the treatments were arranged in pod position in the canopy (main, primary, and secondary stems) that nested to the plant ages $(8,10,12$, and 14 years) were applied. The plants sample were randomly determined by 3 plants per experimental block, and of each position was harvest 3 pods of cocoa.

\section{Observation Variable}

Observation variable including the quality of pods i.e. pod length $(\mathrm{cm})$, pod diameter $(\mathrm{cm})$, and pod weight $(\mathrm{g})$, meanwhile the bean productivity, seed number per pod and dry seed production $(\mathrm{g})$.

\section{Data Analysis}

The variance analysis was used to the data management and the Duncan's Multiple Range Test at 95\% significant level was applied. To judge the relationships between treatments observed was determined by regression analysis.

\section{RESULTS \\ Physical Quality of Cocoa Pod}

Variance analysis of pod position on canopy and plant ages of all variable observed were significantly difference. The mean values of pod quality based on their position on canopy and different plant ages was shown in Table 1.

Table 1. Physical quality of cocoa pod based on their different position in canopy and plant ages

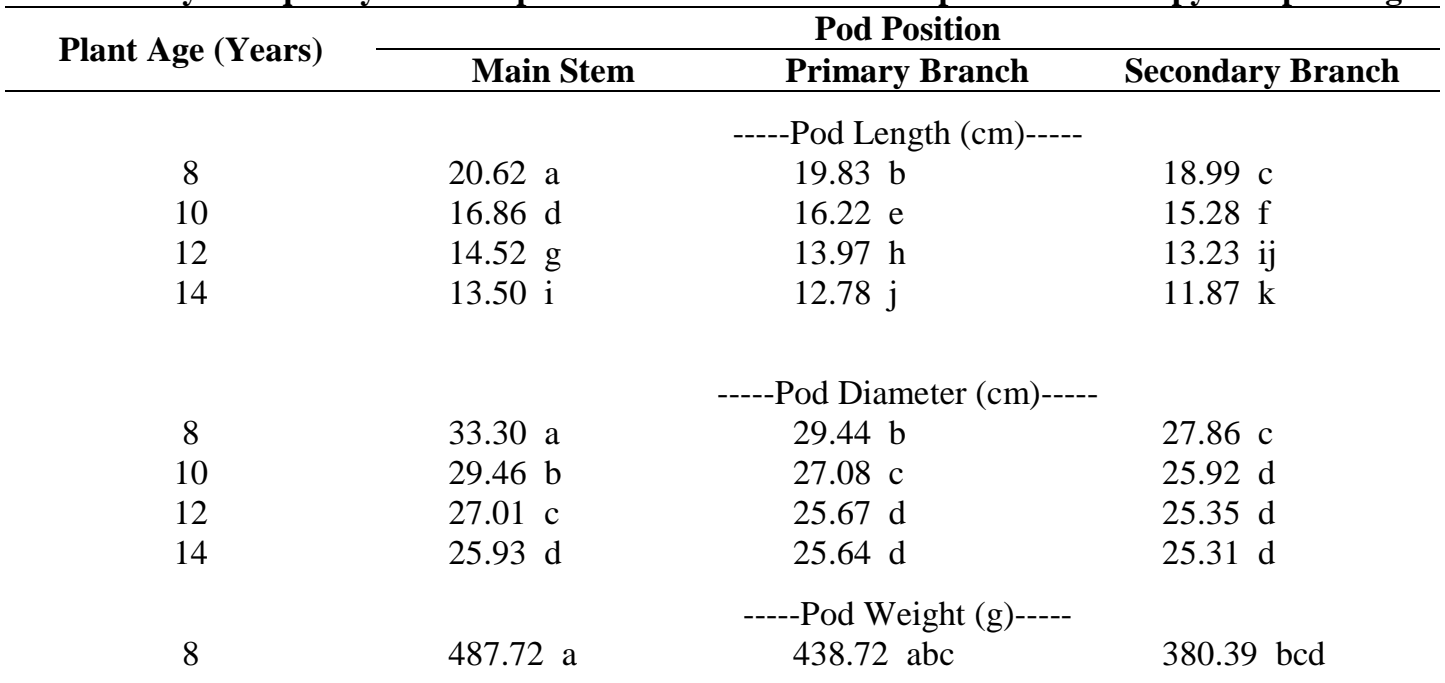


ISSN (Online): 2455-3662

EPRA International Journal of Multidisciplinary Research (IJMR) - Peer Reviewed Journal

Volume: 7 | Issue: 8 | August 2021|| Journal DOI: 10.36713/epra2013 || SJIF Impact Factor 2021: 8.047 || ISI Value: 1.188

\begin{tabular}{llll}
10 & $495.50 \mathrm{a}$ & $421.17 \mathrm{ad}$ & $360.78 \mathrm{bcd}$ \\
12 & $456.17 \mathrm{ab}$ & $405.33 \mathrm{ad}$ & $344.67 \mathrm{~cd}$ \\
14 & $422.78 \mathrm{ad}$ & $365.11 \mathrm{bcd}$ & $326.83 \mathrm{~d}$ \\
\hline
\end{tabular}

Notes: Mean values followed by the same letters in the same column based on the variable observed were not significantly difference based on Duncan's Multiple Range Test at $95 \%$.

Cocoa Pod Length. Table 1 showed that the cocoa pod length was obtained on the main stem with $20.62 \mathrm{~cm}$ length and significantly different with other treatments. Contrasted to the lower value of cocoa pod length i.e.
$11.87 \mathrm{~cm}$ was observed in the 14 years old that lied on the secondary branch and are differencies with the other treatments.

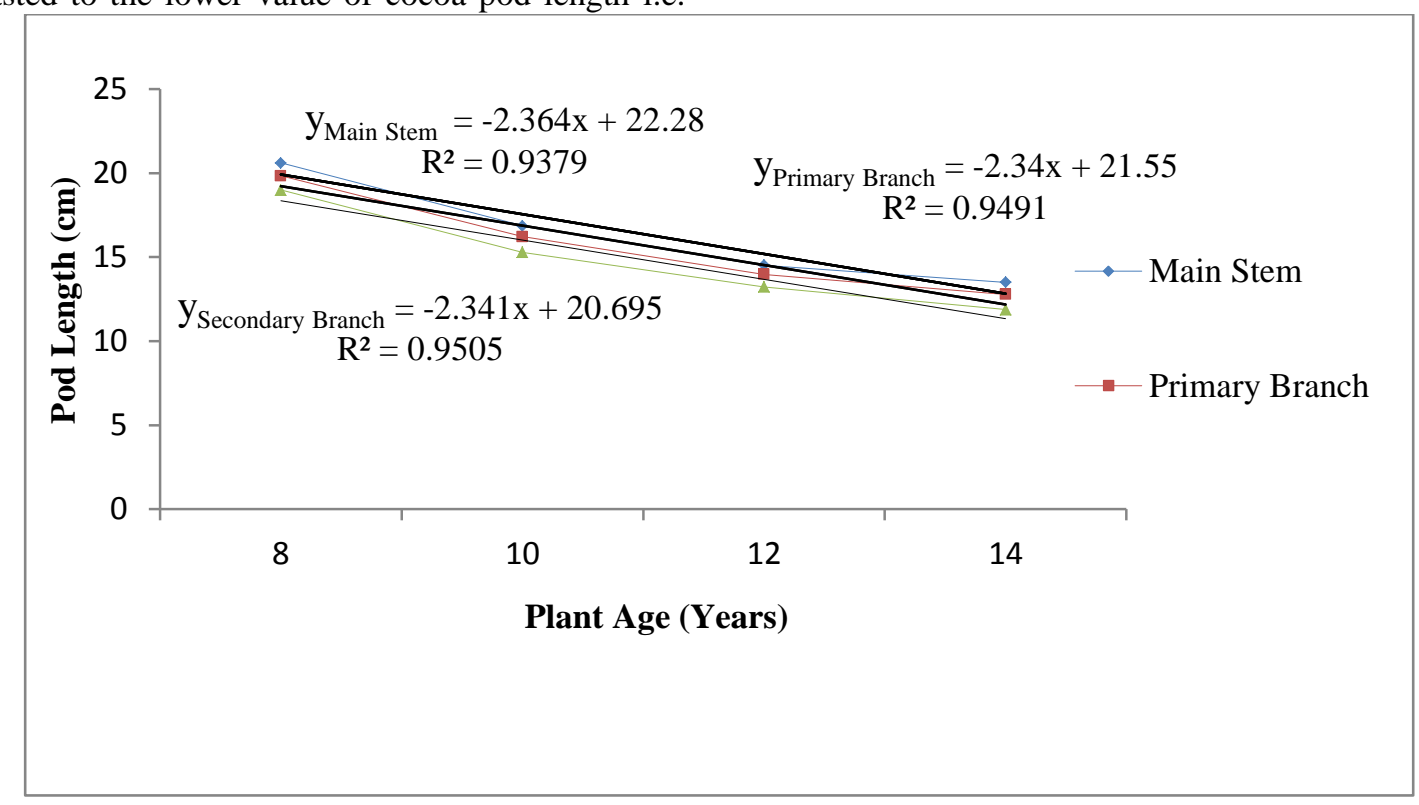

Figure 1. The relationships between different cocoa pod length position on canopy and the plant ages

The highest value of cocoa pod length was obtained in the main stem, primary and secondary branches, respectively. The eight years old of the plant age resulted the more lengthy bean pod than the another treatments i.e. the 10,12 , and 14 years old. This has been clearly that the older the cocoa plant ages, the lower the value of its pod length (Figure 1).

Cocoa pod diameter. The highest value $(33.30 \mathrm{~cm})$ of pod diameter was obtained in the eight years old of the plant ages and in the main stem of pod position (Table 1) with significantly different with another treatments. Whereas the lower value of cocoa pod diameter $(25.31 \mathrm{~cm})$ was obtained in the 14 years old of the plant and significantly different with another treatments, i.e. the 8,10 , and 12 years old of the plant ages. This condition was not significantly difference with the eight and 12 years old of the plant ages, and the primary branch of cocoa pod position, also the eight years old of the plant ages and the cocoa pod position at the secondary branch position. 


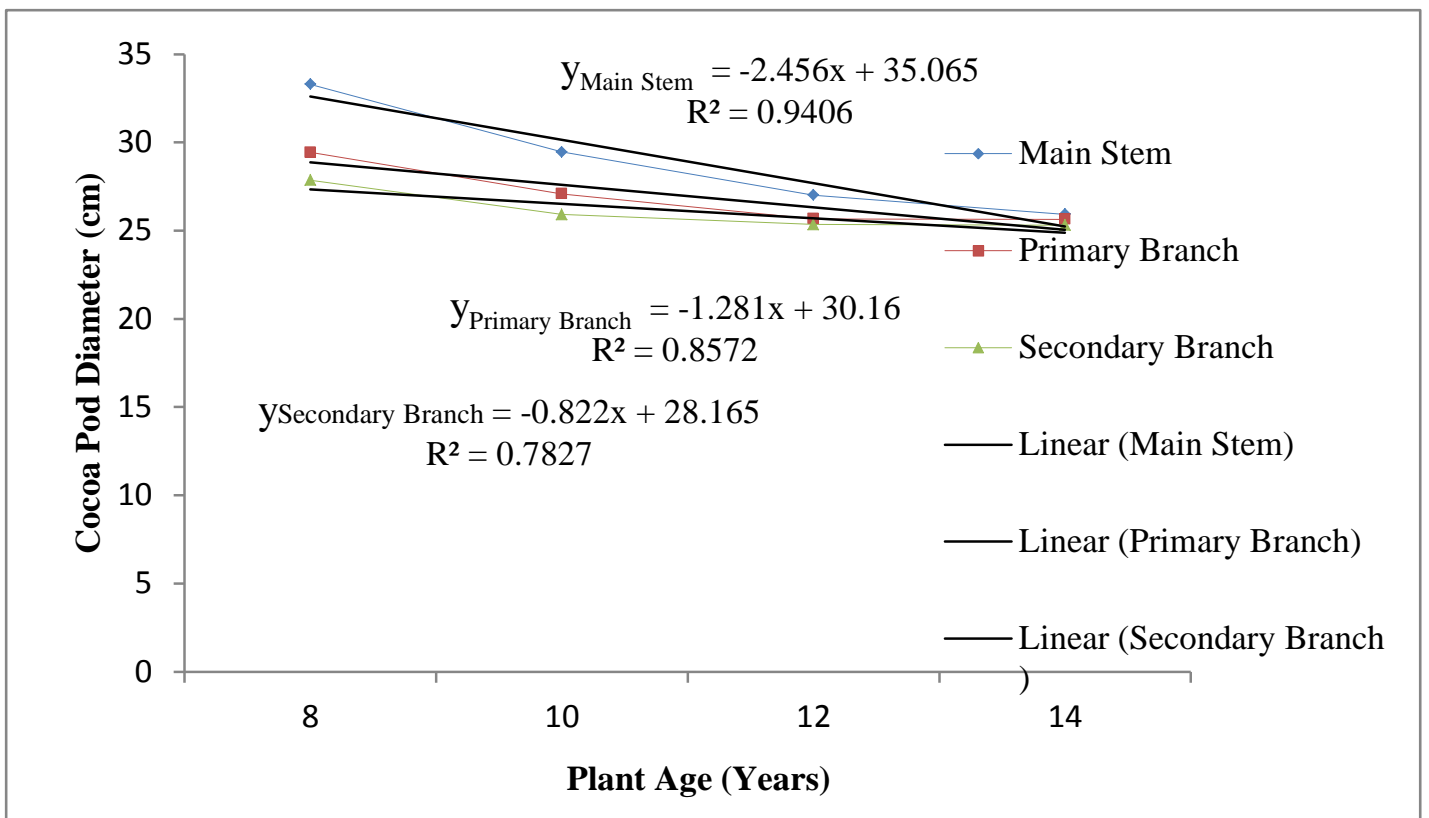

Figure 2. The relationships between different cocoa pod diameter position on canopy and the plant ages

Cocoa pod weight. Table 1 have shown that the cocoa pod weight was higher $(487.72 \mathrm{~g})$ on the main stem of cocoa pod position at eight years old of the plant ages, and significantly different with the cocoa pod harvested at primary branch of 14 years old of the plant ages, also significantly different with cocoa pod position on secondary branch at $8,10,12$, and 14 years old of the plant ages. Contrastly, the lower cocoa pod weight $(326.83 \mathrm{~g})$ was achieved in secondary branch position at 14 years old of the plant, and significantly difference with another treatments, except the cocoa pod were obtained from the main stem at 8 , 10,12 years old, also the cocoa pod obtained from the main stem at eight years old.

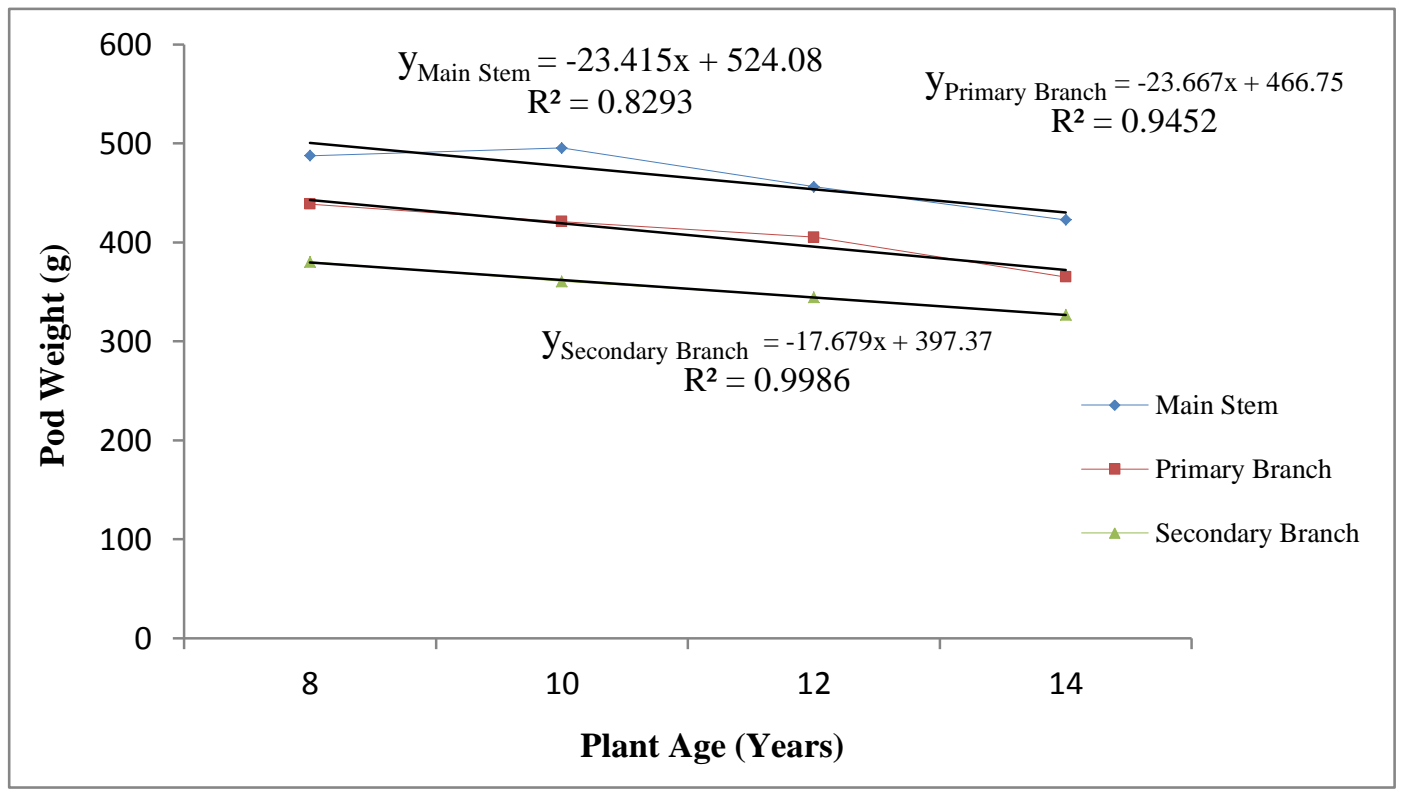

Figure 3. The relationships between different cocoa pod weight position on canopy and the plant ages

\section{Cocoa Bean Productivity}

Variance analysis of pod position on canopy and plant ages of all variable observed on cocoa been productivity were significantly difference. Mean values of cocoa bean productivity basen on its canopy position at different plant ages was indicated in Table 2. 
ISSN (Online): 2455-3662

EPRA International Journal of Multidisciplinary Research (IJMR) - Peer Reviewed Journal Volume: 7 | Issue: 8 | August 2021|| Journal DOI: 10.36713/epra2013 || SJIF Impact Factor 2021: 8.047 || ISI Value: 1.188

Table 2. Cocoa bean productivity based on its position on canopy and different plant ages

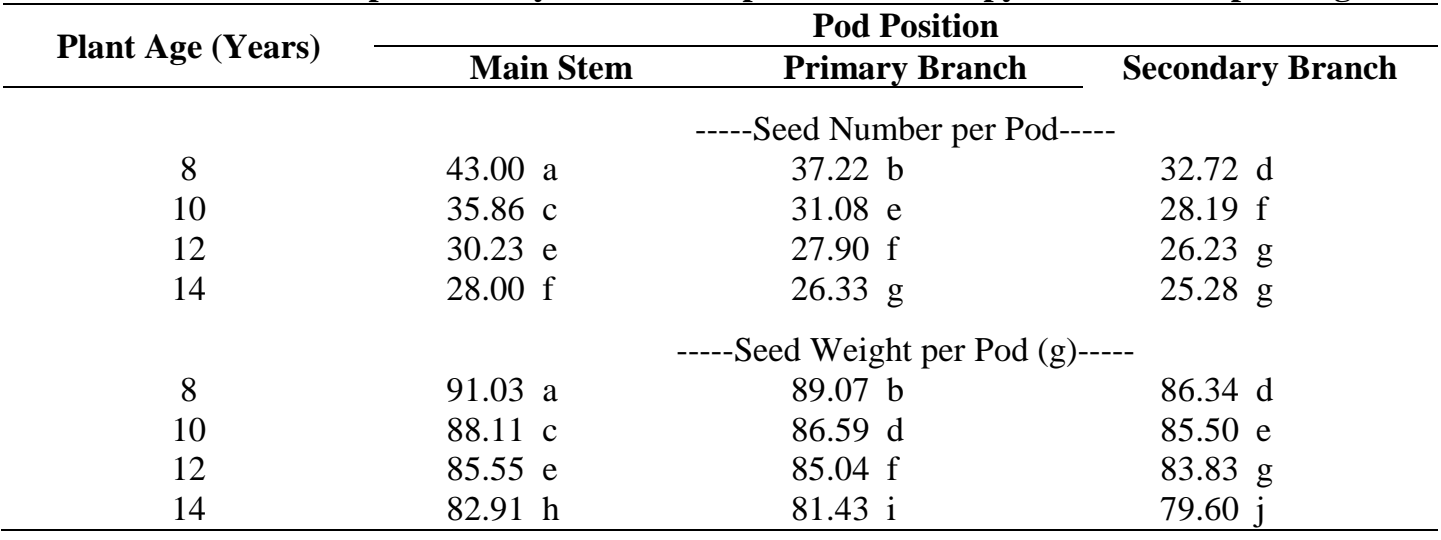

Notes: Mean values followed by the same letters in the same column based on the variable observed were not significantly difference based on Duncan's Multiple Range Test at $95 \%$ position in the canopy, except from the primary branch position at 14 years old, and 12 years old of the plant ages at secondary branch position.

This indicated that the extending ages of the Seed Number per Pod. Table 2 indicated that the number of cocoa seeds from main stem was the higher values than that of from both primary and secondary branches. The seeds number per pod was different from different position, either in main stem, primary branch, or in secondary branch. The higher values of seeds number (43.0 seeds) was indicated in main stem at eight years old of the plant, and significantly different with another treatments. In contrast, the lower number and significantly different of seeds number of different treatments was obtained from secondary branch plant, the lower values of the seeds number obtained that decreasing the number of seeds number per cocoa pod. The seeds number per pod at eight years old of the plant will vary according to their total number, but this variation will decreasing significantly when the plant ages was increasing so that the 14 years old of the plant ages will yielding the decreasing seeds number per pod (Figure 4).

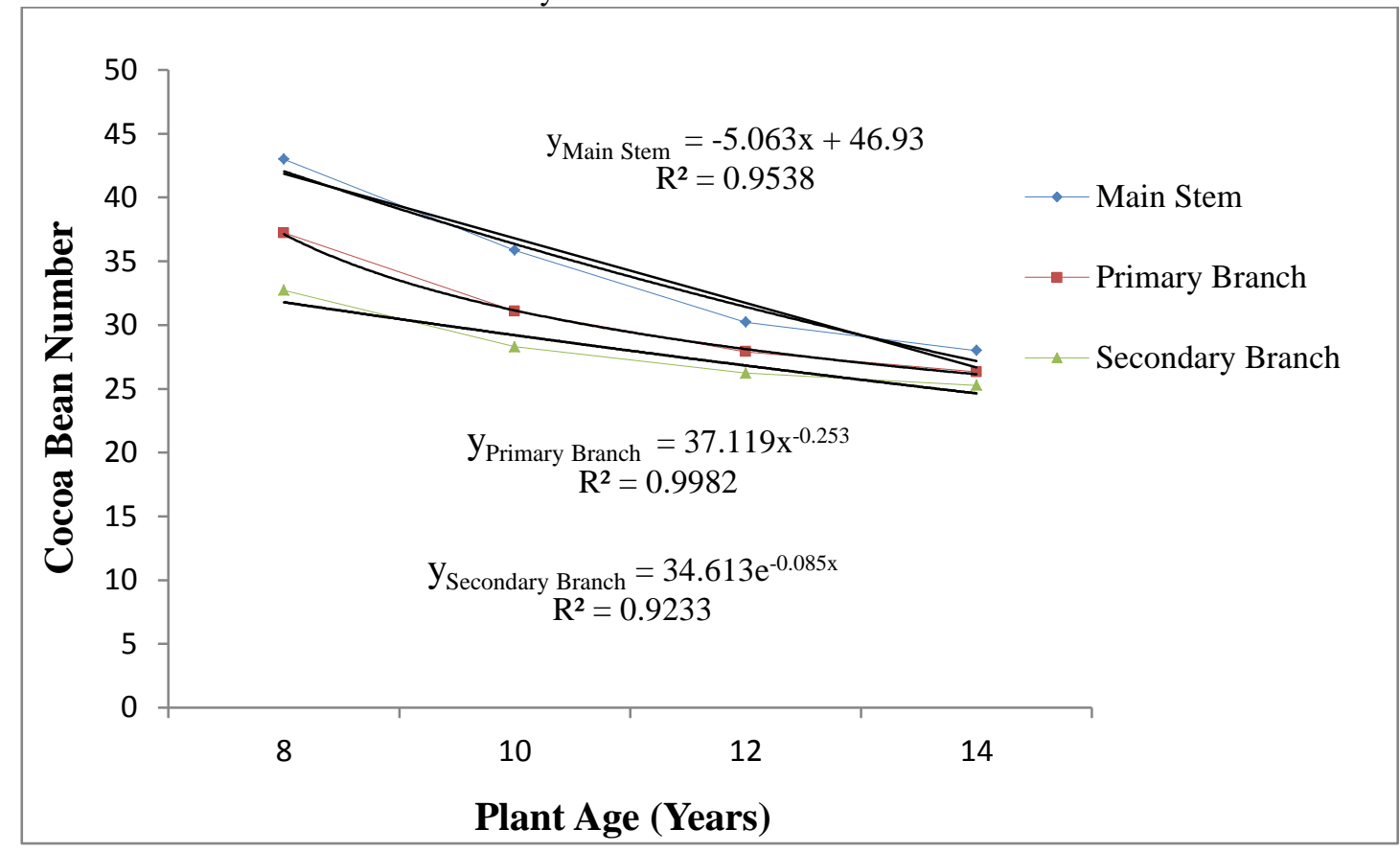

Figure 4. The relationships between different bean cocoa number position on canopy and the plant ages 
Cocoa Seed Weight per Pod at $10 \%$ Water

Content. In Table 5, showed that the higher values of seeds weight $(91.03 \mathrm{~g})$ was obtained in the eight years old of the plant ages and signifantly different with another treatments. In contrast, the lower weight of the seeds $(79.60 \mathrm{~g})$ was indicated in secondary branch position in the canopy at 14 years old of the plant age.

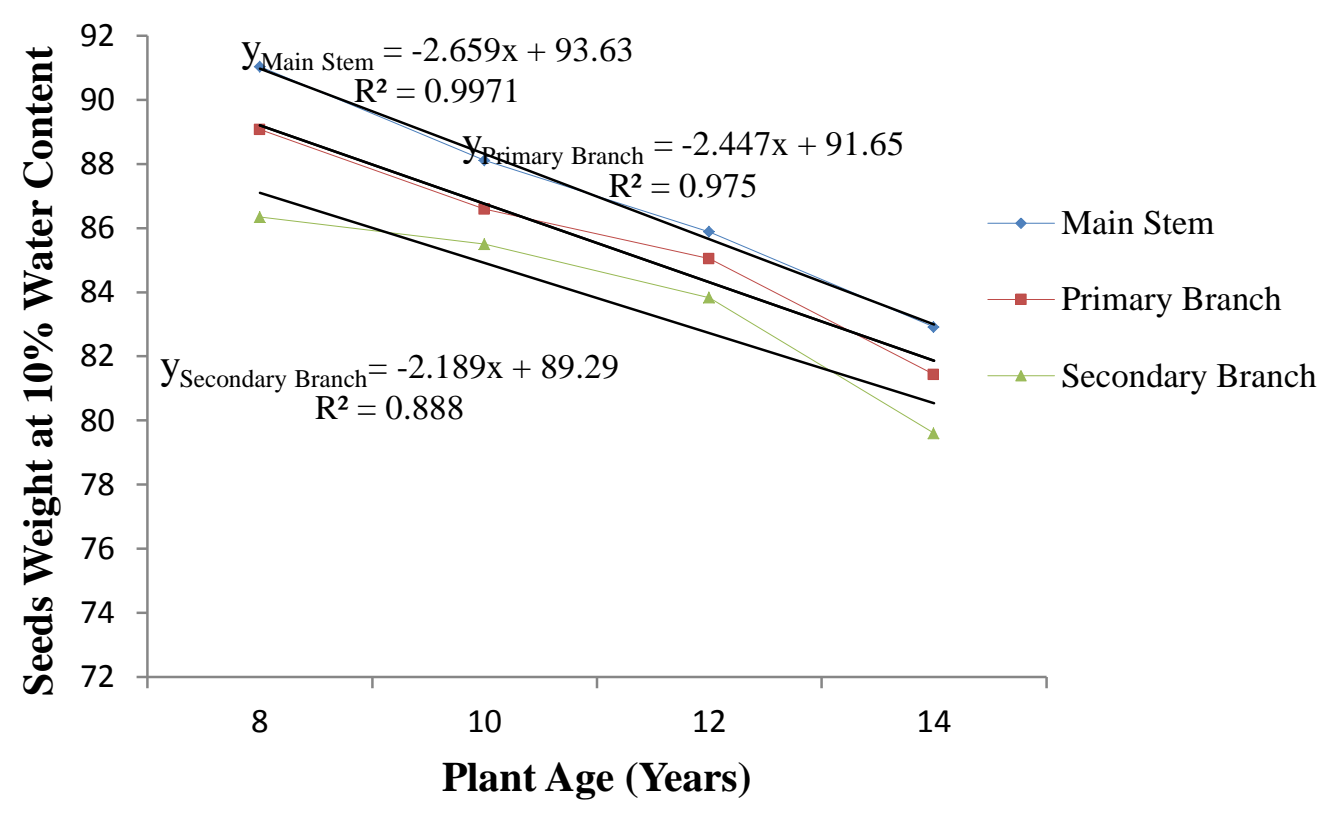

Figure 5. The relationships between different cocoa seeds weight per pod position on canopy and the plant

\section{DISCUSSION}

Cocoa pod in one side was as a result of so called sink, a source of assimlate wich strongly related to the plant characteristics, growth environment, and plantation management. But, in another one side, the seeds were the resultant of the cocoa pod as the main seed sceleton. Growth and development of the seed was depend mainly on pod condition either in physical or physiologica condition.

Based on observed variable (Table 1) have shown that the effect of pod position in canopy and plant ages on the length, diameter, and weight of the pods, seeds number, and seeds production per pod were significantly different. The positive effect of pod position in main stem, primary and secondary branches were due to the variably photosynthate distribution between main stem, primary and secondary branches. The difference photosynthate distribution in the whole plant was as a consecuency of the departure range of source production and their useness, floem cross sectional obstacle, and the existency of floem bottleneck [8].

Photosynthate tranportation supply was departly loading more on the main stem compared to the primary and secondary branches. It is due to the photosynthate flow from source to pod on main stem resulted the pod development was more intensively in it

\section{ages}

compared to the primary and seondary branches. Photosynthate distribution to another part of the plant was mainly determined by the pod position on the whole plant or canopy, and the competitiveness level between pods, and genetical and environmental factors [8]. Besides, the large allocation of photosynthate to cocoa pod that lies on to the main stem was possibly because this part have more floem tissue compared to the primary and secondary branches. Also, pod (sink) position in canopy have the higher strength compared to the primary and secondary branches. This was in similar with Gardner and Mitchel [9], that photosynthate partition in whole plant was affected by fitohormone, sink activity, and the amount of sink strength. The growth and development of pod cocoa bean was different with pod position in the main stem, primary and secondary branches. This suspected that the photosynthate was translocated from the source or plant leaf. Relevant result of this research showed in Jurniati [10], observation in which the weight of cocoa pod tissue in main stem was $407.311 \mathrm{~g}$ per pod and more higher than in the primary and secondary branches in average i.e. $383.873 \mathrm{~g}$ per pod. The placenta weight of cocoa pod in main stem was 15.662 $\mathrm{g}$ per pod and more higher than the cocoa pod that lies on the primary and secondary branches i.e. $13.902 \mathrm{~g}$ per pod. Cocoa bean weight including their pulp in 
main stem was $93.893 \mathrm{~g}$ in average and lower than in the branch in average i.e. 87.377 per pod. But, pod weight without pulp in main stem was $66.377 \mathrm{~g}$ per pod in average and lower than the branches i.e. $62.187 \mathrm{~g}$ per pod in average. The cocoa bean number per pod in main stem was 42.0 seeds which higher than in the primary and secondary branches i.e., 40.5 seeds per pod, both in averages. Water content of cocoa bean in main stem was $6.42 \%$ in average that higher than that of the primary and secondary branches around $6.39 \%$.

Hasbawati [11], reported that the measurement of pod and cocoa bean features was based on the pod position in the canopy. In general, the measurement of pod in main stem was weightest and heaviest comapared to the primary and secondary branches. This has been due to the cocoa pod in main stem have capability to get some growth factor including the light and $\mathrm{CO}_{2}$ with higher values compared to the primary and secondary branches. The young cocoa pod have capability to do photosynthetical acitivity as a result of the existency of chlorophyl compartment so that the light and $\mathrm{CO}_{2}$ were needed.

Research results showed that the plant ages was significantly different on pod length, pod diameter, pod weight, bean number, and dry bean cocoa production. The eight years old of the cocoa plant have higher pod length, pod diameter, pod weight and dry bean production and higher than the other, decreasingly those variable when the plant increasingly the plant ages. This was in similar with the Rubio and Siswanto [12], observations that maximum production was achieved after six to seven years, and the production was declained after this years. The 10 years age of plant or more tend to be decreasing their canopy performances and unoptimal production achievement. In the field experiment indicating that the old plant tend to be vegetatively growth decreasing wich the number and wide of leaf formation were decreased.

In general, the eight years old of the plant was the higher production and the good physical quality of cocoa pod. It was assessed that the plant ability in absorbing the nutrition in the soil was more maximal which affected the production, and pod and bean quality. Also, the eight years age of the plant resulting their higher production and physical quality. This was similar with Alam et al. [13], that the age of plant was affected the quality of cacao pod and its dry seed. This was also similar to Sarawa et al. [8], that the eight years old of the plant indicating the pod from the primary branch which higher content of protein, fat, and dry seed were higher.

Research results indicated that except plant ages and pod position in canopy were also affecting cocoa production and it physical quality. Cocoa pod, in general, was situated in main stem so that the physical quality become more good compared to the pod which lies on primary and secondary branches. It is because the pod position was in the main stem that openly from direct sunrise expossure and also most nearly from surface of soil so that the temperature was lower than that of another part of the plant. The temperature was the factor that influnces on vegetative growth, flowering of the plant, and pod development [14].

Based on regression analysis on Figure 1, 2, 3, and 4 have shown that the correlation (R) values between pod position in canopy and plant ages were signuficantly different with value of $92.88 \%$. This value means that the relationship between the plant ages and pod position in canopy were strongly related to pod length, pod diameter, pod weight, bean numbers, and bean production.

\section{CONCLUSION}

Based on this experimental observation, the authors have concluded that: Pod position on canopy and plant ages on productity and physical quality of cocoa bean production have interaction effects. The eight years old of the plant age tend to be resulted the significant pod production and physical properties. The pod position on canopy in main stem resulting the best seeds physical characters and productivity compared to the primary and secondary branches.

\section{REFERENCES}

1. Komalasari (2009) Analisis Faktor-faktor yang mempengaruhi penawaran Ekspor Biji Kakao. Scientific Repository IPB. http://repository.ipb.ac.id/handle/123456789/12960.

2. Internasional Cocoa Coffrence (ICCO) (2016) Overview of cocoa supply and demand. In ICCO cocoa market outlook Coference. London. https://www.icco.org/wp-content/uploads/2019/07/01Laurent-Pipitone-1.pdf

3. Hasibuan AM, Nurmallina R, Wahyudi A (2012) Analysis of performance and competitiveness of Indonesian cocoa and its intermediate products in the international market. Jurnal Tanaman Industri dan Penyegar. 3(1):57-69. DOI: http://dx.doi.org/10.21082/jtidp.v3n1.2012.p5770.

4. Liyanda M., Abubakar K, Yusya', A (2012) Analysis of land suitability criteria for cocoa production of three cluster development in Pidie District. J. Agrista. 16(2):62-79.

5. Alam N., Muhammad S.S, Gatot S.H (2010) Cacao fruit characteristics harvesting at various growth location Abova Sea Level and Maturity Classes. J. Agroland 17(2):123-130.

6. Fauzi A, Faisal, Muhammad Rafli (2017) Effects of position of cacao (Theobroma cacao L.) on the trees and its seed treatments to seed germination. Jurnal Agrium. 14(1):1-7. 
7. Kusumastuti T.C (2013) Matarity level and fruit position on plant and its effects on the yields and quality of cacao seeds (Theobroma cacao L.). $\operatorname{Agro}^{U P Y} V(1): 38-48$.

8. Sarawa, Muhidin, Dirvamena Boer, Halim and Asriningsih (2017) The content fat, protein, and dry weight of cocoa beans (Theobroma cacao L.) from different fruit on the canopy at different ages of the plant. J. Bioscience Research. 14(4):1261-1268.

9. Gardner F.P, Pearce R.B, and Michell R.L (1991) Fisiologi Tanaman Budidaya. Terjemahan Herwati Susilo dan Subyanto. Universitas Indonesia.

10. Jurniati (2013) Pola Sebaran Karakteristik Fisik Biji Kakao (Theobroma cacao L.) Berdasarkan Posisi Buah pada Pohon. Skripsi Fakultas Pertanian, Institut Pertanian Bogor. Indonesia.

11. Hasbawati (2006) Karakteristik Fisik Biji Buah Kakao Menurut Posisinya Pada Pohon. Fakultas Pertanian dan Kehutanan, Universitas Hasanuddin Makassar. Indonesia.

12. Rubyo and Siswanto (2012) Improvement and Development Production of Cocoa in Indonesia. Buletin RISTRI 3(1):33-48.

13. Alam N, Muhardi andn Nurhaeni (1997) Survey Mutu Kakao Rakyat di Kabupaten Donggala. Laporan Hasil Penelitian Dosen. Fakultas Pertanian Universitas Tadulako. Palu.

14. Almeida, AAF and Valle, R.R. 2007. Ecophysiology of the cacao tree. Braz. J. Plant-Physiol. 19(4):425-448. 